\title{
From the Desk of the Honorary Secretary General
}

Dear Members,

I have pleasure to inform you that following an invitation from International Institute of Welding a eleven member delegation from IIW-India comprises of M/s. R Srinivasan, President, Parimal Biswas, Hony. Secretary General, Aloke Kumar Bose, Director, ANBCC-India, Dr. Mahadev Shome \& Mr. Suman Patra of Tata Steel, Dr. Vivek Patel, Assistant Professor, Dr. Jaykumar Vora, Assistant Professor, and Dr. Vishvesh Badhekha, Associate Professor, Mech. Engg. Dept., School of Technology Pandit Deendayal Petroleum University, Gandhinagar, Prof. G. D. Janakiram and Prof. Murugaiyan Amrithalingam of IIT-Madars, and Mr. Anant Ramkishore of IIT-Roorkee participated in the 70th Annual Assembly \& International Conference of International Institute of Welding (IIW) at Shanghai, China during 25-30th June, 2017. Our team members attended various commission meetings and IAB meetings.

You will also be glad to learn that three welders namely Mr. Ramesh Gawande of Nirmal Industries, Mumbai, Mr. Bhunja Shankar Durga of KEMPII, Chennai and Mr. Pratik Kasare of Mahindras, Mumbai participated in the IIWCWS Arc Cup 2017 Competition held at Shanghai, China during 25-30 June, 2017 organized jointly by the Chinese Welding Society and supported by International Institute of Welding. Mr. Ramesh Gawande won the 2nd place of 1st grade prize of Adult Group in 111/SMAW Process. Mr. Durgashankar Bhunja won the 3rd place of 1st grade prize of Youth Group in 135/GMAW Process and also the 3rd grade prize of Youth Group in Finished-product Welding. Mr. Pratik Kasare won Excellent Prize and the Team India was awarded with a Bronze Cup.

The National Welding Meet (NWM-2017) was held at Bengaluru in 12-13 May, 2017 on the theme Advances in Welding Technology \& Skill Development for Make in India at the M. S. Ramaiah University of Applied Sciences, Peenya Indl. Area, Bangalore. The event was a grand success with an excellent team effort by the committee members with 80 plus delegates. The program was inaugurated by Mr. Ranga Prasad, Director MSME (DI) and Valedictory by Dr. Baldev Raj, Director, NIAS.

Our next mega event, the International Congress 2017 will be held from 7-9 December, 2017 at Chennai Trade Centre, Tamil Nadu concurrently with the 12th International Exhibition WELD-INDIA - 2017 at the same venue. Around 800 delegates and 300 technical papers are to be expected for this event. All members are requested to support this event to make it a grand success.

Further, it has been proposed that next Annual General Assembly including 51st Annual General Meeting of IIW-India will held during 22nd and 23rd September, 2017 at Kolkata. On this occasion IIW-India's various divisions meetings will also be held. I would request you all to attend the AGM and other meetings.

With warm regards

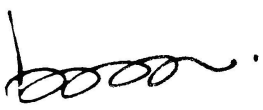

Parimal Biswas

M.No +91 9831052652

E-Mail Id : parimal.biswas@iiwindia.com 